\title{
REVIEW
}

\section{Immunopathology of Hyperinflammation in COVID-19}

Joshua N. Gustine and Dennis Jones

From the Department of Pathology and Laboratory Medicine, Boston University School of Medicine, Boston, Massachusetts

Accepted for publication August 27, 2020.

Address correspondence to Dennis Jones, Ph.D., 670 Albany St., Boston, MA 02118. E-mail: djones1@bu. edu.

\begin{abstract}
The rapid spread of coronavirus disease 2019 (COVID-19), caused by severe acute respiratory syndrome-coronavirus 2 (SARS-CoV-2), has resulted in an unprecedented public health crisis worldwide. Recent studies indicate that a hyperinflammatory syndrome induced by SARS-CoV-2 contributes to disease severity and mortality in COVID-19. In this review, an overview of the pathophysiology underlying the hyperinflammatory syndrome in severe COVID-19 is provided. The current evidence suggests that the hyperinflammatory syndrome results from a dysregulated host innate immune response. The gross and microscopic pathologic findings as well as the alterations in the cytokine milieu, macrophages/monocytes, natural killer cells, T cells, and neutrophils in severe COVID-19 are summarized. The data highlighted include the potential therapeutic approaches undergoing investigation to modulate the immune response and abrogate lung injury in severe COVID19. (Am J Pathol 2021, 191: 4-17; https://doi.org/10.1016/j.ajpath.2020.08.009)
\end{abstract}

In December 2019, severe acute respiratory syndrome-coronavirus 2 (SARS-CoV-2) was identified in Wuhan, China, as the cause of coronavirus disease 2019 (COVID-19). ${ }^{1}$ SARS-CoV-2 represents a novel strain in the coronavirus family, a group of enveloped, positive-sense, singled-stranded RNA viruses. Additional members of this family include the highly pathogenic strains SARS-CoV-1 and Middle East respiratory syndrome-coronavirus (MERS-CoV). SARS-CoV-2 shares significant phylogenetic homology with two bat-derived SARS-like coronaviruses, and primarily uses the angiotensin-converting enzyme (ACE)-2 receptor in humans for cell entry. ${ }^{2}$ After a likely zoonotic spillover event, efficient human-to-human transmission of SARS-CoV-2 was confirmed and resulted in the rapid global spread of COVID-19. ${ }^{3}$ The World Health Organization officially declared COVID-19 a pandemic in March 2020.

Clinically, the disease presentation of COVID-19 is markedly heterogeneous. Patients range from being asymptomatic or having a mild upper respiratory illness to having severe viral pneumonia that requires hospitalization and may progress to cytokine storm, acute respiratory distress syndrome (ARDS), and death. ${ }^{4-6}$ Nearly all patients with severe COVID-19 present with bilateral lung involvement. ${ }^{7}$ The acute onset of impaired oxygenation with noncardiogenic pulmonary infiltrates characterizes ARDS, which develops in $15 \%$ to $40 \%$ of patients with COVID-19-associated pneumonia. ${ }^{4,6,8,9}$ Approximately $80 \%$ of patients with severe disease need supplemental oxygenation, of whom $30 \%$ to $40 \%$ require mechanical ventilation., ${ }^{4,8,9}$ The estimated mortality rate in patients requiring mechanical ventilation approximates $70 \%$ to $90 \%$, and pulmonary failure represents the primary cause of mortality due to COVID-19. ${ }^{6,8,9}$

Akin to SARS-CoV-1 and MERS-CoV, increasing evidence indicates that a hyperinflammatory response to SARS-CoV-2 contributes to disease severity and death in COVID-19. ${ }^{10}$ Patients with severe COVID-19 have elevated clinical inflammatory markers and increased serum cytokine and chemokine levels. ${ }^{4}$ These markers of inflammation are prognostic for the requirement of mechanical ventilation, the development of ARDS, and death in COVID-19.4,8,9,11,12 Postmortem analysis has identified a mononuclear inflammatory infiltrate with lymphocytes and macrophages in the lungs, as well as evidence of hemophagocytosis in the bone

\footnotetext{
Supported by NIH grant K22CA230315 (D.J.) and a Ralph Edwards Career Developmental Professorship (D.J.).

Disclosures: None declared.
} 
marrow and reticuloendothelial organs. ${ }^{13-16}$ Collectively, this hyperinflammatory response shares many biological and clinical characteristics with the macrophage-activation syndrome seen in virus-induced hemophagocytic lymphohistiocytosis, ${ }^{17}$ suggesting a significant role of the host innate immune system in the immunopathology of COVID19. Indeed, the efficacy of several immunomodulatory agents in attenuating the immune response to SARS-CoV-2 and in abrogating lung injury is being investigated. In this review, we discuss the inflammatory response in patients with COVID-19; in particular, we highlight the data that suggest that a dysregulated innate immune response drives the hyperinflammatory syndrome in severe COVID-19.

\section{Initial Pathologic Findings}

The pathologic examination of decedents from COVID-19 has provided important insights into the pathogenesis of the disease. The predominant pattern of lung injury associated with COVID-19 has been identified as diffuse alveolar damage accompanied by platelet-fibrin microthrombi in the pulmonary vessels. On postmortem analysis, gross examination have revealed heavy, congested, and diffusely edematous lung parenchyma, consistent with a clinical diagnosis of ARDS. ${ }^{14}$ Microscopy has identified diffuse alveolar hemorrhage in different phases. ${ }^{13,14,16}$ Most cases have been in the early or intermediate proliferative phase with edema, while features consistent with the fibrotic phase were rare. ${ }^{13,14,16}$ Histologic features accompanying the intraalveolar and interstitial exudate have included capillary congestion, dilated alveolar ducts and collapsed alveoli, hyaline membrane formation, and desquamation of pneumocytes. ${ }^{15,16}$ Desquamated pneumocytes have been reported to have an apparent viral cytopathic effect and were present in alveolar spaces. ${ }^{13,16}$ Electron microscopy has identified viral particles within type 1 and type 2 pneumocytes, ${ }^{14,15}$ and immunofluorescence has localized SARS-CoV-2 antigen to the ACE2 ${ }^{+}$bronchiolar epithelium. ${ }^{16}$

It has been reported that in the majority of cases, microthrombi were present in the small- and medium-sized pulmonary arterial vessels. ${ }^{14-16,18}$ Increased levels of $\mathrm{CD}^{+}{ }^{+}$megakaryocytes were also found in alveolar capillaries accompanying the microthrombi. ${ }^{14,15}$ Microthrombi have been identified in nearly all major organs, including the lung, heart, brain, and liver; the location of microthrombi appears to correlate with endothelial ACE2 expression. ${ }^{14-16}$ These microthrombi likely contribute to organ dysfunction and mortality in COVID-19. ${ }^{14-16}$ Ackermann et $\mathrm{al}^{18}$ reported on a study comparing postmortem findings of lung tissue from patients infected with COVID-19, influenza A (hemagglutinin type 1 and neuraminidase type 1; H1N1), and age-matched, uninfected controls. Alveolar capillary microthrombi were ninefold as prevalent in the lungs of COVID-19 patients compared to those in patients with influenza A. ${ }^{18}$ In addition, COVID-19 patients had increased numbers of $\mathrm{ACE} 2^{+}$endothelial cells and significant histologic changes to endothelial cell morphology, including disruption of intercellular junctions, cell swelling, and loss of contact with basement membrane ${ }^{18}$ Consistent with the findings from a previous study evaluating endothelial cells from glomerular capillary loops,${ }^{19}$ electron microscopy identified SARS-CoV-2 viral particles within alveolar endothelial cells. ${ }^{18}$ In vitro studies have also shown that SARS-CoV-2 can directly infect an engineered human blood vessel organoid via the ACE2 receptor. ${ }^{20}$ These findings suggest that direct viral invasion by SARS-CoV-2 may trigger endotheliitis and contribute to endothelial injury in COVID-19. Further work is needed for confirming these data as well as for elucidating the mechanism underlying the prothrombotic state in COVID-19.

In studies to date, all COVID-19 patients had a mononuclear inflammatory infiltrate in the lung parenchyma, composed primarily of lymphocytes and macrophages. ${ }^{13-16,18}$ The lymphocytic infiltrate included both $\mathrm{CD} 4^{+}$and $\mathrm{CD} 8^{+} \mathrm{T}$ cells in the bronchiolar and alveolar interstitium, with a $\mathrm{CD} 4^{+} \mathrm{T}$-cell predominance. ${ }^{14,15,18} \mathrm{CD}^{+} \mathrm{T}$ cells appeared to aggregate around small vessels that often contained microthrombi. ${ }^{14,15}$ Large numbers of $\mathrm{CD}^{+} 8^{+}$macrophages and multinucleated cells were also identified and localized to the alveolar lumen. ${ }^{14-16}$ The presence of macrophages appeared to correlate with disease advancement. ${ }^{14}$ These patient findings have been recapitulated in phenotypic studies using transgenic mice bearing human ACE2 infected with SARS-CoV-2, which showed the characteristic interstitial pneumonia with infiltration of lymphocytes and macrophages in the alveolar interstitium, as well as macrophages in the alveolar lumen. ${ }^{21}$

A recent study identified the presence of hemophagocytosis in the bone marrow and reticuloendothelial organs of patients with COVID-19. Bryce et $\mathrm{al}^{16}$ reported a comprehensive autopsy series of 67 patients who succumbed to COVID-19. In that study, hemophagocytic macrophages were identified in the lymph nodes $(9 / 11)$, spleen $(9 / 22)$, bone marrow (4/6), heart, and liver. Abnormally high mean peak levels of C-reactive protein, ferritin, IL-6, IL-8, and tumor necrosis factor (TNF)- $\alpha$ accompanied the histopathologic findings in these patients. The presence of hemophagocytosis with concomitant elevations in inflammatory cytokines suggests that alveolar macrophage activation can induce a hemophagocytic lymphohistiocytosis phenotype in patients with severe COVID-19. Severe cases of SARS-CoV-1 infection shared similar pathologic findings. ${ }^{22}$

\section{Cytokine Storm}

Early studies reporting outcomes in COVID-19 identified that elevated clinical inflammatory markers were prognostic of disease severity and mortality. ${ }^{8,11}$ Two multicenter, retrospective studies in hospitalized patients in China evaluated predictors of mortality in COVID-19. ${ }^{8,11}$ Nonsurvivors had elevated C-reactive protein, lactate 
dehydrogenase, serum ferritin, and serum IL-6 levels at the time of hospital admission compared to those in survivors. ${ }^{8,11}$ In addition, nonsurvivors had elevated inflammatory markers throughout the entire clinical course, and the clinical deterioration that preceded death tracked with increasing levels of inflammation. ${ }^{8}$ The prevalence of ARDS was also higher in the group with elevated inflammatory markers. ${ }^{9}$

Consistent with these initial clinical findings, plasma sampling from patients with severe COVID-19 revealed a proinflammatory cytokine profile. The initial report included 41 patients admitted to the hospital with COVID-19-related pneumonia in Wuhan, China. ${ }^{4}$ Compared to healthy adults, patients with COVID-19 in that study had higher plasma concentrations of IL-1 $\beta$, IL-1R $\alpha$, IL-7, IL-8, IL-10, basic fibroblast growth factor, granulocyte colony-stimulating factor (G-CSF), granulocyte macrophage (GM)-CSF, interferon (IFN)- $\gamma$, induced protein (IP)-10/CXCL10, monocyte chemotactic protein (MCP)-1/C-C motif chemokine ligand (CCL)-2, macrophage inflammatory protein (MIP)-1 $\alpha /$ CCL3, MIP-1 $\beta / C C L 4$, platelet-derived growth factor, TNF- $\alpha$, and vascular endothelial growth factor. ${ }^{4}$ The mean plasma concentrations of IL-2, IL-7, IL-10, G-CSF, IP-10/CXCL10, MCP-1/CCL2, MIP-1 $\alpha /$ CCL3, and TNF- $\alpha$ were higher in the subgroup in the intensive care unit versus those in non-intensive care unit patients. ${ }^{4}$ A study in 21 patients with COVID-19 admitted with pneumonia reported similar findings; patients with moderate or severe disease had abnormally elevated levels of IL- $1 \beta$, IL-2 receptor (R), IL-6, IL-8, IL-10, and TNF- $\alpha .{ }^{23}$ In a large-scale, retrospective study in 1484 patients at Mount Sinai Hospital (New York, NY), plasma levels of IL-6, IL-8, and TNF- $\alpha$ were higher in those with severe COVID-19. ${ }^{12}$ Moreover, IL-6 and TNF- $\alpha$ levels at the time of hospitalization were independently associated with disease severity and mortality in that multivariate analysis. ${ }^{12}$ Elevated plasma levels of IL-6, IL-8, and TNF- $\alpha$ also peaked before death in an autopsy series of COVID-19 patients, and correlated with pathologic evidence of hemophagocytosis. ${ }^{16}$ These data suggest that a cytokine storm underpins the immunopathology of severe COVID-19.

Tay et $\mathrm{al}^{24}$ proposed a possible mechanism underlying the cytokine storm in severe COVID-19. SARS-CoV-2 is a cytopathic virus that induces the death of infected cells during viral replication. ${ }^{13,16,25}$ Viral replication in epithelial cells may also cause high levels of pyroptosis, ${ }^{26}$ which is an inflammatory form of programed cell death observed in infection with cytopathic viruses. ${ }^{27}$ Pyroptosis could represent an inciting event for the hyperinflammatory response to SARS-CoV-2 infection. $^{28-30}$ IL-1 $\beta$ is released from cells undergoing pyroptosis ${ }^{29}$ and high levels are present in both serum and bronchoalveolar fluid (BALF) in patients with severe COVID19. ${ }^{4,31}$ Pathogen-associated molecular patterns, such as viral RNA, are also released by infected epithelial cells. Neighboring lung epithelial cells and resident alveolar macrophages detect the pathogen-associated molecular patterns using several pattern-recognition receptors. The activation of the pattern-recognition receptors and IL-1R stimulates the secretion of proinflammatory cytokines, including IL- 6 , IFN- $\gamma$, MCP-1/CCL2, MIP-1 $\alpha /$ CCL3, MIP-1 $\beta / C C L 4$, and IP-10/ CXCL4. ${ }^{4,23}$ The cytokines then recruit activated macrophages and $\mathrm{T}$ cells to the site of infection, whereby these immune effector cells potentiate inflammation with additional cytokine secretion and destruction of lung parenchyma. Similar to SARS-CoV-1 and MERS-CoV, the cytokine profile observed in patients with COVID-19 is consistent with a predominant Th1 cell- and classic M1 macrophage-polarized response. ${ }^{10,32}$ Consequently, a proinflammatory feedback loop is established, triggering a cytokine storm that circulates and causes local tissue damage as well as systemic effects, such as septic shock, multiorgan failure, and hemophagocytosis in reticuloendothelial organs. ${ }^{4,16,33}$

Notably, the tropism of SARS-CoV-2 for ACE2 ${ }^{+}$type 2 pneumocytes may contribute to the development of cytokine storm. Viral binding by SARS-CoV-2 to the ACE2 receptor is primarily restricted to type 2 pneumocytes on the lung epithelium. ${ }^{34}$ Although typically associated with surfactant production and alveolar repair, type 2 pneumocytes have a specialized role in the innate immune response. Type 2 pneumocytes express toll-like receptors (TLRs) that activate inflammatory NF- $\kappa B$ signaling in response to binding of viral RNA. ${ }^{35-37}$ The activation of NF- $\kappa B$ triggers the production of cytokines that can induce an inflammatory program in resident macrophages and recruit activated monocytes and $T$ cells to the lung. Accordingly, increased IL-6 levels in hyperplastic type 2 pneumocytes infected with SARS-CoV-2 have been measured. ${ }^{25}$ ACE2 ${ }^{+}$infected pneumocytes also have been reported to express high levels of proinflammatory cytokines (ie, MCP-1/CCL2, TNF- $\alpha$, IL-1 $\beta$, and IL-6) in an autopsy series of patients with SARS-CoV-1 infection; cytokine expression was unchanged in uninfected cells. ${ }^{38}$ Direct invasion and stimulation of TLR-containing $\mathrm{ACE} 2^{+}$type 2 pneumocytes may therefore exacerbate cytokine production in COVID-19.

Dysregulated IFN signaling also likely has an impact on the immunopathology of severe COVID-19. The findings from initial studies have suggested that SARS-CoV-2 can suppress IFN signaling and impair viral clearance from infected cells. SARS-CoV-2 was reported to be sensitive to pretreatment with types I and III IFNs in vitro. ${ }^{39}$ However, a study using infected cell lines, primary bronchial cells, and a ferret model with SARS-CoV-2 infection demonstrated decreased type I and III IFN signatures. ${ }^{39}$ Patients with severe COVID-19 also appeared to have an impaired type I IFN signature compared to that in mild or moderate cases. ${ }^{40}$ Whole-blood transcriptome analysis revealed that the expression of type I IFN was inversely correlated with the viral load and NF- $\kappa \mathrm{B}-$ driven inflammatory response (ie, IL-6 and TNF- $\alpha$ levels) in COVID-19 patients. ${ }^{40}$ Moreover, a multicenter observational study reported that the administration of IFN- $\alpha 2 b$ early in the disease course of COVID19 improved in-hospital mortality in infected patients. ${ }^{41}$ These findings suggest that a weak IFN response during 
early infection with SARS-CoV-2 may allow for the development of severe COVID-19.

Additional work is needed for ascertaining the mechanism that SARS-CoV-2 employs to impair IFN signaling. However, the findings from functional studies in other pathogenic coronaviruses, such as SARS-CoV-1 and MERS-CoV, have elucidated the viral proteins that antagonize IFN signaling and release. Example virulence mechanisms include the inhibition of TNF receptor-associated factor family member-associated NF- $\kappa \mathrm{B}$ activator-binding kinase (TBK)-1-dependent phosphorylation, IFN regulatory factor 3 activation, and IFN production. ${ }^{42-44} \mathrm{~A}$ murine model of SARS-CoV-1 infection also showed that delayed type I IFN signaling and rapid viral replication induced a hyperinflammatory state with lung pathology. ${ }^{45}$ These mice had an excessive accumulation of activated macrophages in the lung, as well as elevated cytokine levels and an inadequate virus-specific T-cell response. ${ }^{45}$ As such, impaired viral clearance of SARS-CoV-2 due to the antagonism of IFN signaling might enable continuous TLR stimulation and pyroptosis of infected type 2 pneumocytes, thereby promoting the hyperinflammatory state observed in severe COVID-19.

\section{Dysregulated Macrophage Activation}

A proinflammatory macrophage microenvironment defines the landscape of bronchoalveolar immune cells in patients with severe COVID-19. In line with initial pathologic findings, single-cell RNA sequencing (scRNA-seq) of BALF collected from COVID-19 patients identified an abundance of macrophages in severe disease. ${ }^{31,46}$ Further analysis revealed that the macrophages are primarily inflammatory monocyte derived, with a relative paucity of resident alveolar macrophages. ${ }^{31}$ The macrophages in severe disease highly express the genes ficolin-1 (FCNI) and SPPI, while in moderate disease they preferentially express $F A B P 4 .{ }^{31}$ Consistent with the cytokine pattern in peripheral blood, ${ }^{4}$ macrophages expressing FCNI and SPPI in BALF have gene-expression signatures characteristic of classic M1 macrophages. ${ }^{31}$ These macrophages express genes that encode peripheral monocyte-like markers (ie, S100A8, FCN1, and CD14), chemokines (ie, MCP1/CCL2, MIPIA/CCL3, and INP10/ $C X C L 10$ ), and inflammatory transcription factors (ie, $N F K B$, STAT1, STAT2, and IFN regulatory factors).

A profibrotic subset of alternative M2 macrophages that express both profibrotic genes (ie, TREM2, TGFB1, and $S P P 1$ ) and immunoregulatory genes (ie, $A 2 M$ and $G P R 3$ ) was also identified in patients with severe COVID-19. ${ }^{31}$ These findings suggest that the pathogenic role of macrophages in severe COVID-19 may extend beyond acute inflammation to include pulmonary fibrosis. Early reports indicate fibrotic lung patterns with reduced diffusion and total lung capacity in survivors of severe COVID-19, as well as persistent ground-glass opacities on imaging at the time of hospital discharge. ${ }^{47,48}$
Gene expression of cytokines and chemokines has been reported to be markedly increased in lung macrophages. Based on scRNA-seq data, lung macrophages from patients with severe COVID-19 had increased expression of $I L 1 B$, IL6, TNF, and genes encoding several chemokines, including $M C P 1 / C C L 2, M I P 1 A / C C L 3, M I P 1 B / C C L 4$, and $M C P 3 / C C L 7 .^{31,46,49}$ These chemokines are potent recruiters of inflammatory monocytes to the site of infection. Conversely, patients with moderate disease have been reported to express higher levels of CXCL16, which can bind to the CXCR6 receptor and attract $\mathrm{CD} 8^{+} \mathrm{T}$ cells that may be specific for SARS-CoV-2. ${ }^{31}$ In both severe and moderate cases, the gene expression levels of the CXCR3 ligands CXCL9, CXCL10, and CXCL11 were higher compared to those in healthy controls. ${ }^{31}$ These transcriptional changes in lung macrophages also correlated with BALF cytokine levels. Patients with severe disease had significantly higher levels of proinflammatory cytokines in BALF, especially IL-1 $\beta$, IL-6, IL-8, TNF- $\alpha$, and IFN- $\gamma \cdot{ }^{31,49}$ Collectively, these data suggest that lung macrophages recruit inflammatory monocytes and produce cytokines that contribute to hyperinflammation in severe COVID-19.

A significant expansion of inflammatory monocytes is also present in the peripheral blood of COVID-19 patients. Flow cytometric analysis have been used for identifying increased populations of $\mathrm{CD}_{14}^{+} \mathrm{CD} 16^{+}, \mathrm{GM}_{-} \mathrm{CSF}^{+} \mathrm{CD} 14^{+}$, and IL- $6^{+} \mathrm{CD} 14^{+}$subsets of inflammatory monocytes. ${ }^{50,51}$ The percentage of $\mathrm{CD} 14^{+} \mathrm{CD} 16^{+}$monocytes producing IL- 6 was correlated with disease severity. ${ }^{50}$ Data from scRNA-seq of peripheral blood mononuclear cells demonstrated similar findings, wherein $\mathrm{CD} 14^{+} \mathrm{IL}-1 \beta^{+}$monocytes, IFN-activated monocytes, and $I L I B$-associated inflammasome signatures were observed. ${ }^{52-54}$ Akin to lung macrophages, inflammatory monocytes in the peripheral blood showed an enrichment of genes encoding cytokine signaling and inflammation characteristic of classic M1 macrophages. ${ }^{52}$ The scRNA-seq analysis additionally suggested that cytokine activation drives the systemic expansion of monocyte populations in the peripheral blood of COVID-19 patients. ${ }^{52,54}$ Hence, the cytokine environment likely generated by type 2 pneumocytes and resident alveolar macrophages after SARS-CoV-2 infection triggered the expansion and recruitment of inflammatory monocytes to the lung.

Pathologic stimulation of TLR/IL-1R signaling represents a significant mechanism activating inflammatory monocytes and macrophages in COVID-19. It has been shown that after TLR/ IL-1R stimulation, Bruton tyrosine kinase (BTK) drives the signaling cascade that activates both NF- $\mathrm{BB}$ and nucleotidebinding oligomerization domain-containing protein-like receptor protein (NLRP)-3 inflammasome secretion of IL-1 $\beta .^{29,55-57}$ Accordingly, recent data showed increased phosphorylation of BTK in IL- $6^{+} \mathrm{CD} 14^{+}$monocytes derived from patients with severe COVID-19. ${ }^{51}$ The entire population of monocytes had phosphorylated BTK, ${ }^{51}$ consistent with the notion of systemic monocytic activation. Transcriptomic profiling of whole blood and single monocytes revealed similar 
findings. Patients with severe COVID-19 had increased expression of TLR and $I L I R$ and downstream signaling molecules (ie, MYD88, IRAK4, IRAK1, TRAF6, and RELA/ p65). ${ }^{52,53}$ The expression of these signaling molecules also tracked with disease severity in one patient with longitudinal samples. ${ }^{53}$ Myeloid differentiation primary response protein 88 (MyD88) is an adaptor protein that triggers BTK activation and mediates signaling for IL-1, IL-18, and all TLRs except TLR3. ${ }^{58}$ MyD88 $^{-1-}$ mice infected with SARS-CoV-1 exhibited decreased lung pathology and cytokine levels as well as impaired monocyte recruitment to the lung versus MyD88 ${ }^{\text {WT/WT }}$ mice. ${ }^{59}$ Likewise, in a small cohort of severe COVID-19 patients, treatment with a BTK inhibitor normalized C-reactive protein and IL-6 levels and improved oxygenation. ${ }^{51}$ The findings from these studies indicate that targeting the TLR/IL-1R signaling cascade may attenuate the hyperinflammatory response in severe COVID-19.

\section{Impaired Natural Killer Cell Response}

Studies have shown that peripheral natural killer (NK) cells are depleted and exhibit an exhausted phenotype in patients with severe COVID-19. Peripheral NK cell counts were significantly lower in COVID-19 patients with severe disease versus those in patients with mild disease or in healthy controls. ${ }^{52,60-63}$ Whereas antiviral cytotoxic CD56 ${ }^{\mathrm{dim}} \mathrm{NK}$ cells were primarily depleted in ventilator-dependent patients, all COVID-19 patients had decreased cytokine-producing CD56 ${ }^{\text {high }}$ NK cells peripherally. ${ }^{60}$ The uniform reduction of CD56 ${ }^{\text {high }}$ NK cells suggests that peripheral NK cells do not directly contribute cytokines toward the cytokine storm in COVID-19. The percentage of peripheral NK cells expressing the activation markers CD16, CD107a, IFN- $\gamma$, IL-2, and TNF- $\alpha$ was also significantly lower in COVID-19 patients compared to healthy controls, as was the mean fluorescence intensity of cytotoxic granzyme B. ${ }^{61,62}$ scRNA-seq revealed evidence of exhausted NK cells with increased transcription of the inhibitory receptor genes LAG3, PDCD1, and HAVCR $2{ }^{60}$ Both NK and $\mathrm{CD} 8^{+} \mathrm{T}$ cells also had increased expression of the immune checkpoint natural killer group 2 member A (NKG2A), which inhibits cell cytotoxicity. ${ }^{61}$ The successful treatment of COVID-19 is associated with the reversal of functional NK cell exhaustion, as evidenced by the down-regulation of NKG2A in the convalescent period. ${ }^{61}$

It remains unclear whether the peripheral NK cell depletion is due to the trafficking of cells to infected lung tissue or cell death. A study employing bulk RNA-seq analyzed the immune composition of BALF from COVID-19 patients collected a median of 8 days after symptom onset. ${ }^{46}$ The results demonstrated no change in the proportion of activated NK cells, while COVID-19 patients had a decreased proportion of resting NK cells in BALF versus healthy controls. ${ }^{46}$ Conversely, a study using scRNA-seq of BALF collected a median of 12 days after symptom onset reported increased NK cells in COVID-19 patients. ${ }^{31}$ The discrepant findings between studies could have been attributed to the timing differences in BALF sample collection, and suggest that NK cells may be recruited to the lung later in the disease course of COVID-19. ${ }^{64}$ Trafficking of NK cells is further supported by the expansion of lung macrophages that produce CXCR3 ligands (CXCL9, CXCL10, and CXCL11) in COVID-19. ${ }^{31}$ CXCR3 has been previously shown to promote NK cell recruitment to the lung in influenza infection. ${ }^{65}$ It is possible that cell death may also contribute to peripheral NK-cell depletion, given that the transcription of TP53 and apoptosis pathways in peripheral lymphocytes are up-regulated in COVID-19 patients. ${ }^{49}$ While the absence of ACE2 receptors makes SARS-CoV-2 infection of NK cells unlikely, ${ }^{34}$ circulating cytokines could play a role, given that peripheral NK-cell counts are inversely correlated with serum IL-6 levels. ${ }^{62}$ Additional studies are nonetheless needed for delineating the processes involved in peripheral NK-cell depletion, including whether the cytokine storm leads to NK-cell apoptosis.

The cytokine milieu also may confer the exhausted phenotype of peripheral NK cells in COVID-19. In particular, studies have reported that IL- 6 and TNF- $\alpha$ impaired the cytolytic function of NK cells..$^{54,61,62,66-68}$ In healthy donor NK cells, in vitro stimulation of the soluble IL-6R by IL- 6 reduced the production of perforin and granzyme, which can be reversed by IL-6R antagonism with tocilizumab. ${ }^{66}$ These findings suggest that IL-6 might hasten the down-regulation of granzyme expression on NK cells reported in COVID-19. ${ }^{61}$ However, additional experiments are needed for confirming these findings in NK cells derived from COVID-19 patients. The decreased expression of CD16 on NK cells indicates that reduced NK-cell licensing is also likely occurring; CD16 expression was reported to be inversely correlated with serum IL-6 levels in COVID-19 patients. ${ }^{62}$ In addition, ligandreceptor analysis with scRNA-seq of peripheral blood revealed interactions between inflammatory monocytes and NK cells in severe COVID- $19 .{ }^{54}$ The data showed that TNF- $\alpha$ may interact with its receptor, TNFR1, on NK cells. ${ }^{54}$ The impact of this cytokine-receptor interaction in COVID-19 needs investigation, but in the tumor microenvironment it results in the down-regulation of the major NK cell-activating receptor NKp46, especially on CD56 ${ }^{\text {high }}$ NK cells. ${ }^{67}$ Taken together, these findings suggest that crosstalk with monocytes and macrophages via cytokines might mediate NK-cell dysfunction and impair the clearance of SARS-CoV-2. ${ }^{68}$ Persistent infection with SARS-CoV-2 could subsequently exacerbate the proinflammatory feedback loop underlying the cytokine storm in severe COVID-19.

\section{Role of T Cells in Hyperinflammation}

The occurrence of a profound lymphopenia in patients with COVID-19 is well established. The absolute lymphocyte count is prognostic of disease severity and mortality, with significant reductions in peripheral $\mathrm{CD}^{+}$and $\mathrm{CD}^{+} \mathrm{T}$ cells reported in both moderate and severe cases of 
COVID-19. ${ }^{4,8,9,11,23,61,63}$ Serum cytokine levels are inversely correlated with $\mathrm{CD}^{+}$and $\mathrm{CD} 8^{+}$T-cell counts, and improved cytokine levels have been associated with the reversal of lymphopenia in the convalescent period of recovered patients. ${ }^{4,8,12,61,63}$ In decedents who had lymphopenia, autopsy evaluations have revealed the extensive cell death of lymphocytes in the lymph nodes and spleen; SARS-CoV2-infected spleens and lymph nodes also were found to have overexpressed the apoptotic protein Fas. ${ }^{16,69}$ Likewise, transcriptomic analysis identified up-regulation of apoptotic pathways in lymphocytes from the peripheral blood of COVID-19 patients. ${ }^{49}$ Hemophagocytic macrophages present in the spleen and lymph nodes accompanied the lymphocyte depletion, ${ }^{16}$ suggesting a role for aberrantly activated macrophages in lymphopenia. These macrophages have been found to express high levels of IL-6, which may promote lymphocyte necrosis and apoptosis. ${ }^{69}$ Indeed, antagonism of the IL-6R with tocilizumab resulted in increased peripheral lymphocyte counts in COVID-19. ${ }^{63}$ Trafficking of peripheral $\mathrm{T}$ cells to the lung also likely contributes to the lymphopenia. As previously discussed (Initial Pathologic Findings), autopsy studies have reported a pulmonary lymphocytic interstitial infiltrate with $\mathrm{CD} 4^{+}$and $\mathrm{CD} 8^{+} \mathrm{T}$ cells, ${ }^{13-16}$ and scRNA-seq of BALF identified a heterogeneous expansion of $\mathrm{CD} 8{ }^{+} \mathrm{T}$ cells. ${ }^{31}$ Additional studies are needed for clarifying the mechanism and functional impact of lymphopenia, such as on the clearance of SARS-CoV-2.

The T-cell composition of surviving lymphocytes may exacerbate the hyperinflammatory state in COVID-19. In conjunction with IL-6- and GM-CSF-producing monocytes, patients with severe COVID-19 have been found to have increased proportions of pathogenic Th1 $\mathrm{CD} 4^{+} \mathrm{T}$ cells that express IL-6, GM-CSF, and IFN- $\gamma .^{61}$ In particular, patients requiring intensive care unit admission had significantly higher proportions of Th1 cells co-expressing GMCSF and IFN- $\gamma \cdot{ }^{61}$ These Th1 cells can produce proinflammatory cytokines that contribute to the cytokine storm and migrate to the lung to potentiate tissue damage. Zheng et $\mathrm{al}^{61}$ postulated that GM-CSF links the activation of inflammatory monocytes and Th1 cells in severe cases. Moreover, flow cytometry has revealed decreased levels of immunosuppressive T-regulatory cells in patients with severe COVID-19. ${ }^{23}$ scRNA-seq of peripheral blood similarly identified depleted T-regulatory cells, as well as upregulated inflammatory and cytokine pathways in $\mathrm{CD} 4^{+} \mathrm{T}$ cells. ${ }^{52}$ These findings collectively suggest that the reduction in T-regulatory cells disrupts immune homeostasis and promotes a central role for $\mathrm{CD}^{+} \mathrm{Th} 1$ cells in the pathogenesis of COVID-19-related hyperinflammation.

\section{Neutrophils and Neutrophil Extracellular Traps}

Increasing evidence indicates that the dysregulated myeloid response to SARS-CoV-2 extends to neutrophils in severe COVID-19. An elevated absolute neutrophil count and neutrophil/lymphocyte ratio have been reported to be prognostic of ARDS and death in COVID-19. ${ }^{4,8,9,11,12,23}$ Patients with severe COVID-19 also had increased levels of neutrophil extracellular traps (NETs),${ }^{70,71}$ which are webs of DNA material with antimicrobials and oxidant enzymes extruded by neutrophils to control infections. Serum samples collected from patients hospitalized with COVID-19 had higher levels of cell-free DNA, myeloperoxidase (MPO)-DNA complexes, and citrullinated histone H3 (CitH3) compared to those from patients with mild/moderate disease and healthy controls ${ }^{70,71}$; the latter two markers are considered specific for NET remnants. Elevated plasma MPO-DNA complexes have been associated with a decreased $\mathrm{PaO}_{2} / \mathrm{FiO}_{2}$ ratio, a need for mechanical ventilation, and death in COVID-19. ${ }^{70,71}$ Increasing levels of MPO-DNA complexes also tracked with oxygen deterioration in patients with longitudinal samples. ${ }^{71}$ The milieu of patients with COVID-19 appears to promote the formation of NETs, as the exposure of healthy neutrophils to serum collected from hospitalized COVID-19 patients has been reported to trigger significant NETosis. ${ }^{70,71}$ Further work is needed for delineating the mechanism of NET formation in COVID-19, but the activation of neutrophils by viral nucleic acids and cytokines might have a role. ${ }^{70-72}$

Importantly, NETs may contribute to the development of lung injury and microthrombi in COVID-19. Dysregulated NETosis has been previously shown to cause excessive lung injury and immunothrombosis in response to other respiratory viruses and bacteria. ${ }^{73} \mathrm{~A}$ recent study that evaluated autopsy lung specimens for NETs reported pathologic evidence suggestive of dysregulated NETosis in COVID-19. ${ }^{70}$ Immunofluorescence revealed a neutrophilic infiltrate in the lungs, with numerous $\mathrm{Cit}^{-\mathrm{H}^{+}}{ }^{+}$and $\mathrm{MPO}^{+}$neutrophils as well as lattices of extracellular DNA with $\mathrm{Cit}-\mathrm{H} 3$ and MPO.$^{70}$ In addition, the study reported the co-localization of $\mathrm{Cit}^{-} 3^{+}$neutrophils likely undergoing NETosis with platelet factor 4 -positive platelets in pulmonary blood vessels, ${ }^{70}$ suggesting a possible role of NET and platelet interaction in microthrombi formation in COVID-19. Whether excessive immunothrombosis by NETs triggers platelet aggregation and the prothrombotic state in COVID-19 warrants investigation.

\section{Multisystem Inflammatory Syndrome in Children}

Recent case series of children have identified a hyperinflammatory vasculopathy associated with COVID-19, deemed the multisystem inflammatory syndrome in children (MIS-C). ${ }^{74-77}$ This syndrome has been reported to have a wide range of clinical presentations that overlap with Kawasaki disease, toxic shock syndrome, and macrophageactivation syndrome/hemophagocytic lymphohistiocytosis. Nearly all patients with MIS-C have presented with fever. ${ }^{74-77}$ Multiple organ systems have been reported to be 
involved in most patients, with the gastrointestinal (92\%), cardiovascular (80\%), hematologic (76\%), mucocutaneous (74\%), and respiratory (70\%) systems most commonly involved. $^{74}$ The majority of patients have required admission to the intensive care unit for treatment. ${ }^{74-77}$ Invasive and noninvasive mechanical ventilation for respiratory insufficiency or failure has been needed in $20 \%$ and $17 \%$ of patients, respectively. ${ }^{74}$ The mortality rate from MIS-C has been estimated as approximately $0 \%$ to $2 \% .^{74-77}$

An important finding in MIS-C has been the high incidence of cardiovascular involvement. In reports from the United States and Europe, the majority of patients had elevated brain natriuretic peptide and troponin levels. ${ }^{74-77}$ Nearly half of the patients had hypotension or cardiogenic shock, which prompted vasopressor support in one-quarter of patients. ${ }^{74-77}$ On echocardiography, ventricular dysfunction (ejection fraction $<55 \%$ ) was identified in approximately half of patients. ${ }^{74-77}$ Approximately $8 \%$ to $21 \%$ of patients also had coronary artery aneurysm identified in either the left descending artery or the right coronary artery, consistent with a Kawasaki-like vasculitis presentation of MIS-C. ${ }^{74-77}$

The immunologic findings in MIS-C have been similar to those described in adults with severe COVID-19. Nearly all MIS-C patients had multiple laboratory markers of inflammation, including an elevated erythrocyte sedimentation rate, C-reactive protein, and ferritin. ${ }^{74-77}$ Serum cytokine analysis showed elevated IL-6, IL-10, and soluble IL-2R levels. ${ }^{76} \mathrm{~Pa}-$ tients with MIS-C also displayed lymphopenia, including reduced levels of $\mathrm{CD}^{+}$and $\mathrm{CD} 8^{+} \mathrm{T}$ cells as well as NK cells. ${ }^{76}$ Notably, the majority of MIS-C patients had positive SARS-CoV-2 serologies, ${ }^{76}$ and the median time interval elapsed between COVID-19 symptom onset and MIS-C symptom onset was 25 days. $^{74}$ These findings support the current hypothesis that MIS-C represents an immune-mediated SARS-CoV-2 postinfectious process. ${ }^{74,76}$ Although MIS-C is a rare complication of COVID-19, additional studies are needed for understanding the pathophysiology, therapeutic management, and long-term sequelae of this complication.

\section{Therapeutic Targeting of Hyperinflammation}

The evidence of a dysregulated host immune response has prompted the investigation of immunomodulatory therapies for abrogating lung injury in COVID-19. There are $>2500$ studies of COVID-19 currently registered with clinicaltrials. gov, including many evaluating immunomodulators alone or in combination with other agents. These clinical trials will need to determine the optimal disease stage of COVID-19 at which immunomodulators are most effective and safe in patients with hyperinflammation. The published clinical trials of immunomodulators in COVID-19 are reviewed in the subsequent paragraph and the developmental stage of each clinical approach as well as ongoing randomized studies are summarized in Table 1.
Corticosteroids have widespread inhibitory effects on the immune system and are efficacious in managing acute inflammatory processes. The randomized, controlled, openlabel RECOVERY trial (Dexamethasone in Hospitalized Patients with Covid-19-preliminary report ${ }^{78}$ evaluated the efficacy of the corticosteroid dexamethasone $(n=2104)$ versus usual care $(n=4321)$ in hospitalized COVID-19 patients. Dexamethasone $6 \mathrm{mg}$ once daily was given for up to 10 days. The study demonstrated a significantly lower 28-day mortality in patients randomized to receive dexamethasone versus usual care $(22.9 \%$ versus $25.7 \%$; $P<0.001){ }^{78}$ In a prespecified subgroup analysis, dexamethasone reduced 28-day mortality by $36 \%$ in patients on mechanical ventilation ( $\mathrm{HR}=0.64 ; 95 \% \mathrm{CI}, 0.51$ to 0.81 ) and by $18 \%$ in patients receiving oxygen without mechanical ventilation ( $\mathrm{HR}=0.82 ; 95 \% \mathrm{CI}, 0.72$ to 0.94$)$, whereas dexamethasone had no benefit in patients receiving no respiratory support $(\mathrm{HR}=1.19 ; 95 \% \mathrm{CI}, 0.91$ to 1.55$) .^{78}$ Dexamethasone was also more effective in patients randomized to receive treatment for $>7$ versus $\leq 7$ days after the onset of COVID-19 symptoms $(P<0.001){ }^{78}$ Dexamethasone was the first therapy reported to improve survival in patients with COVID-19.

The identification of respiratory support as a predictor of dexamethasone efficacy has provided insights into the disease stages of COVID-19. Previous studies have shown that inflammatory markers track with disease progression and clinical deterioration in COVID-19. ${ }^{4,8,9,11,12,23}$ Consistent with these findings, the benefit of immune suppression with dexamethasone was apparent in only patients requiring respiratory support, as well as those randomized to receive treatment for $>7$ days after symptom onset. ${ }^{78}$ These data suggest that the patients were in a later disease stage dominated by immunopathology. Conversely, patients not requiring respiratory support, who were likely without significant inflammation, had no benefit, and a trend of increasing death rate from dexamethasone treatment. ${ }^{78}$ It is possible that dexamethasone may have suppressed the viral clearance of SARS-CoV-2 in these patients. The majority of patients without respiratory support had symptoms for $<1$ week at the time of randomization, ${ }^{78}$ which corresponds to the timing of peak viral replication of SARS-CoV-2. ${ }^{79}$ The use of systemic corticosteroids have been shown to impair viral clearance in patients with SARS-MERS or SARSCoV-1 infection. ${ }^{80,81}$ Longitudinal evaluation of inflammatory markers and viral loads with dexamethasone use will further clarify these findings in COVID-19.

The cytokine storm in patients with severe COVID-19 has prompted the evaluation of selective cytokine inhibitors. Tocilizumab, a recombinant humanized monoclonal antibody directed against both the soluble and membrane-bound forms of IL-6R, has been reported to be effective in the treatment of the cytokine-release syndrome associated with chimeric antigen receptor T-cell therapy. ${ }^{82,83}$ Case series have suggested that tocilizumab is effective in the treatment of severe COVID-19, wherein patients had rapid decreases 
Table 1 Selected Candidate Immunomodulator Therapies for Severe COVID-19

\begin{tabular}{|c|c|c|c|}
\hline Drug class & Rationale & Clinical evidence & Current status \\
\hline Corticosteroids & Broad immunosuppression & $\begin{array}{l}\text { Randomized, controlled RECOVERY trial } \\
\text { showed dexamethasone decreased } \\
28 \text {-day mortality vs supportive care } \\
(22.9 \% \text { vs } 25.7 \%) \text { in hospitalized } \\
\text { COVID-19 patients; subgroup } \\
\text { analysis revealed improved survival } \\
\text { for patients on mechanical } \\
\text { ventilation (HR }=0.64 ; 95 \% \text { CI, }\end{array}$ & $\begin{array}{l}\text { Treatment with dexamethasone has } \\
\text { been incorporated into NIH } \\
\text { COVID-19 Treatment Guidelines for } \\
\text { hospitalized patients who are on } \\
\text { mechanical ventilation and } \\
\text { patients who require supplemental } \\
\text { oxygenation but not on mechanical } \\
\text { ventilation* }\end{array}$ \\
\hline
\end{tabular}

IL-6 antagonists Activity in cytokine release syndrome associated with CAR T cell therapy

IL-1 antagonists

BTK inhibitors

Hydroxychloroquine In vitro activity against SARS-CoV-2; inhibits TLR signaling and cytokine production

\begin{abstract}
Activity in macrophage activation syndrome and hemophagocytic lymphohistiocytosis
\end{abstract}

Inhibits TLR signaling and cytokine production in activated macrophages; prevents lethal lung injury in mouse influenza model
$0.51-0.81$ ) and patients requiring supplemental oxygenation but not on mechanical ventilation $(\mathrm{HR}=0.82 ; 95 \% \mathrm{CI}, 0.72-0.94)$, but no survival benefit for patients not requiring supplemental oxygenation ( $\mathrm{HR}=1.19 ; 95 \% \mathrm{CI}$, 0.91-1.55)

Limited; retrospective, nonrandomized cohort studies suggest that benefit in severe COVID-19, but confirmation required

Limited; retrospective, nonrandomized cohort studies suggest that benefit in severe COVID-19, but confirmation required

Limited; possible benefit suggested from small case series and uncontrolled pilot study that showed normalization of inflammatory markers (ie, CRP, IL-6) and improved oxygenation with treatment, but confirmation required

Inconsistent results from retrospective, nonrandomized cohort studies; recent randomized, controlled trials demonstrated no benefit in COVID-19 patients with mild/moderate or severe disease as well as when used for post-exposure prophylaxis

\author{
Randomized, controlled trials in \\ progress (NCT04306705, \\ NCT04346355, NCT04320615, \\ NCT04331808, NCT04335071, \\ NCT04322773, NCT04333914, \\ NCT04330638) \\ Randomized, controlled trials in \\ progress (NCT04341584, \\ NCT04324021, NCT04330638)
}

Randomized, controlled trials in progress (NCT04375397, NCT04380688, NCT04382586)

Emergency Use Authorization revoked by US FDA on June $15,2020^{\dagger}$

\footnotetext{
Detailed information for each clinical trial can be accessed by searching the unique NCT identifier number on www.clinicaltrials.gov.

*https://www.covid19treatmentguidelines.nih.gov/immune-based-therapy/immunomodulators/corticosteroids, last accessed August 19, 2020.

†https://www.fda.gov/news-events/press-announcements/coronavirus-covid-19-update-fda-revokes-emergency-use-authorization-chloroquine-and, last accessed August 19, 2020.

BTK, Bruton tyrosine kinase; CAR, chimeric antigen receptor; CRP, C-reactive protein; FDA, US Food and Drug Administration; HR, hazard ratio; NIH, National Institutes of Health; RECOVERY, Randomized Evaluation of Covid-19 Therapy ${ }^{78}$; TLR, toll-like receptor.
}

in inflammatory markers (ie, C-reactive protein, ferritin, Ddimer) and improved oxygenation (ie, $\mathrm{PaO}_{2} / \mathrm{FiO}_{2}$ ratio) and lymphocyte count. $^{84-86}$ Two recent nonrandomized, observational studies recapitulated these findings and demonstrated that tocilizumab might improve survival in severe COVID-19. ${ }^{87,88}$ Somers et al $^{87}$ reported that tocilizumab use was associated with a $45 \%$ reduced risk for death versus supportive care in patients with COVID-19 on mechanical ventilation $(\mathrm{HR}=0.55 ; 95 \% \mathrm{CI}, 0.33$ to 0.90$)$. Tocilizumab use was also associated with an increased risk for superinfections in this population of mechanically ventilated patients (54\% versus $26 \% ; P<0.001$ ), although there was no difference in the 28-day case fatality rate among patients receiving tocilizumab with and without 


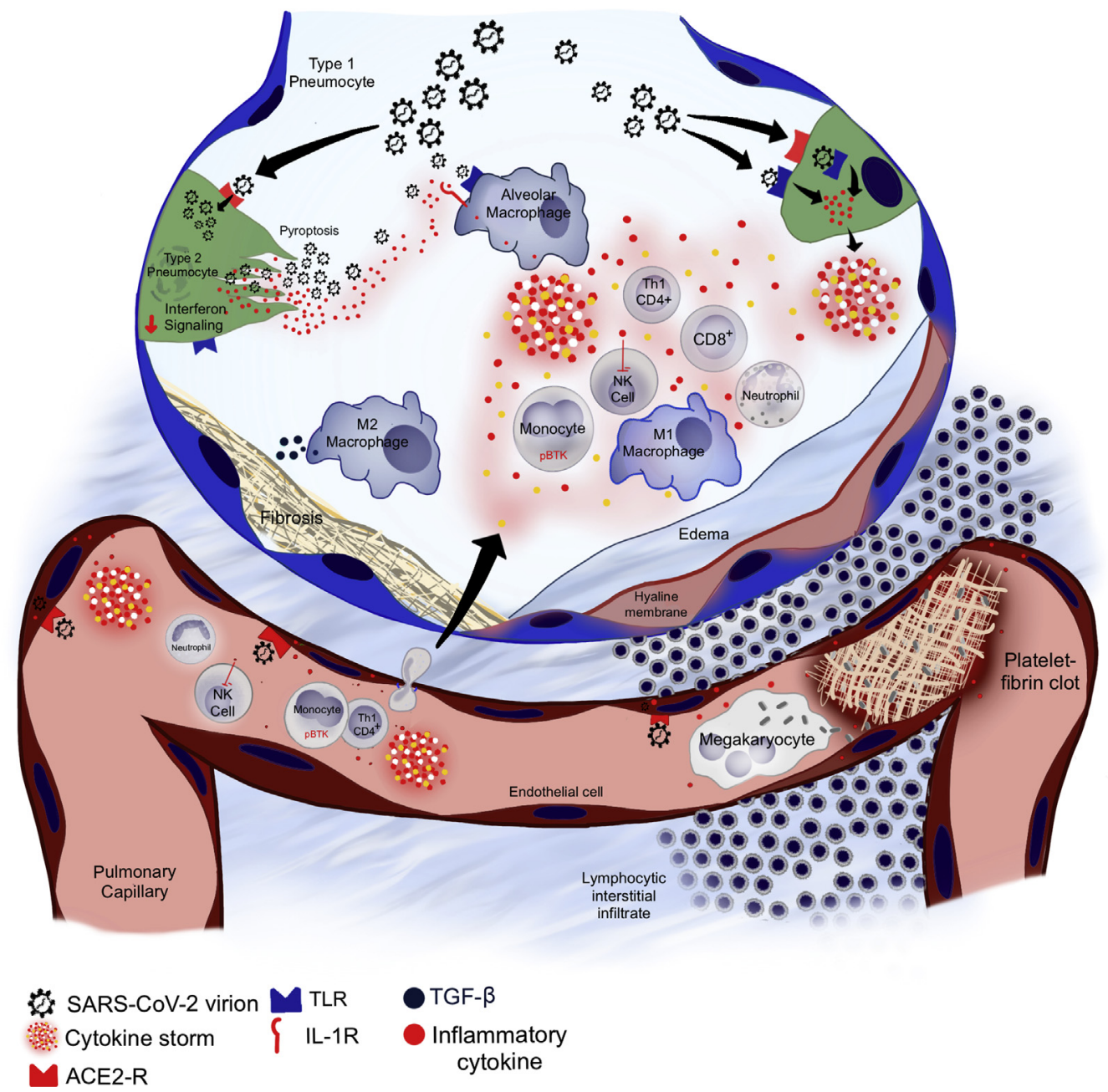

Figure 1 Disease mechanism of severe COVID-19 after severe acute respiratory syndrome coronavirus 2 (SARS-CoV-2) infection. SARS-CoV-2 primarily infects type 2 pneumocytes expressing the ACE2 receptor in alveoli. The active viral replication of SARS-CoV-2 causes the host cell to undergo pyroptosis and release viral nucleic acids and proinflammatory cytokines. These are recognized by pattern-recognition receptors on neighboring pneumocytes and resident alveolar macrophages, which trigger the production of proinflammatory cytokines and chemokines, including IL-1 $\beta$, IL- 6, IL-8, GM-CSF, TNF- $\alpha$, IFN- $\gamma$, IP-10/ CXCL10, MCP-1/CCL2, MIP-1 $\alpha / C C L 3$, and MIP-1 $\beta / C C L 4$. Inflammatory monocytes, CD4 ${ }^{+}$and $C D 8^{+} \mathrm{T}$ cells, neutrophils, and NK cells are then recruited to the lung parenchyma and interstitium. The monocyte-derived classic M1 macrophages and CD4 ${ }^{+} \mathrm{T}$ cells exacerbate inflammation by producing additional cytokines; a profibrotic subset of alternative M2 macrophages are also recruited to the lung. A proinflammatory feedback loop is established that triggers a circulating cytokine storm and leads to acute respiratory distress syndrome, septic shock, and hemophagocytic macrophages in reticuloendothelial organs. Direct invasion of $\mathrm{ACE}^{+}$endothelial cells by SARS-CoV-2 may also trigger an endotheliitis in the pulmonary vasculature. pBTK, phosphorylated Bruton's Tyrosine Kinase.

superinfection $(22 \%$ versus $15 \% ; P=0.42) .{ }^{87}$ Likewise, in patients admitted with COVID-19-related pneumonia, Guaraldi et al ${ }^{88}$ reported that tocilizumab use was associated with a $39 \%$ reduced risk for invasive mechanical ventilation or death versus supportive care $(\mathrm{HR}=0.61 ; 95 \% \mathrm{CI}, 0.40$ to $0.91 ; P=0.02$ ).

Two nonrandomized, observational studies have also evaluated the efficacy of the IL-1R antagonist anakinra in blocking the activity of IL-1 $\beta$ and inflammasome signaling in patients with severe COVID-19. ${ }^{89,90}$ Anakinra has been reported to be effective in patients with secondary hemophagocytic lymphohistiocytosis, including when triggered by viral infections, as well as sepsis in those with hyperinflammation. ${ }^{91,92}$ In severe COVID-19, anakinra use was associated with a rapid reduction in C-reactive protein and a progressive improvement in respiratory function (ie, $\mathrm{PaO}_{2} / \mathrm{FiO}_{2}$ ratio). ${ }^{89,90}$ Cavalli et al ${ }^{89}$ reported a higher 21-day survival with anakinra use versus supportive care ( $90 \%$ versus $56 \% ; P=0.009$ ), and Huet et al ${ }^{90}$ showed that anakinra use was associated with a $78 \%$ decreased risk for mortality versus supportive care $(\mathrm{HR}=0.22 ; 95 \% \mathrm{CI}$, 0.10 to $0.49 ; P=0.0002$ ). Similar to IL-6R antagonism with tocilizumab, anakinra use also was associated with an increased risk for infection. ${ }^{89,90}$ Randomized, controlled studies of the clinical benefits of tocilizumab, anakinra, and additional selective cytokine inhibitors in severe COVID-19 are ongoing.

The dependence on BTK to transmit proinflammatory TLR/IL-1R signaling in monocytes has prompted the 
consideration of BTK inhibitors in the abrogation of the cytokine storm in COVID-19. BTK inhibitors are approved and widely used in patients with B-cell malignancies and chronic graft-versus-host disease. In these patients, the use of the BTK inhibitor ibrutinib was associated with markedly reduced levels of inflammatory cytokines and chemokines (ie, IL-6, TNF- $\alpha$, GM-CSF, IP-10/CXCL10, MCP-1/CCL2, MIP-1 $\alpha / C C L 3$, and MIP-1 $\beta / C C L 4)$ that overlap with those elevated in the plasma and BALF in severe COVID-19 patients. $^{93-95}$ Ibrutinib was reported to block pulmonary cytokine production and fatal lung injury in a murine model of influenza. ${ }^{96}$ Treon et al ${ }^{97}$ first reported a possible clinical benefit of ibrutinib in a case series of Waldenström macroglobulinemia patients infected with COVID-19. Results from a pilot study of another BTK inhibitor, acalabrutinib, were subsequently reported in patients hospitalized with severe COVID-19 $(n=19) .{ }^{51}$ After the initiation of acalabrutinib treatment, most patients had normalization of C-reactive protein, IL-6, and lymphocyte levels. ${ }^{51}$ This decrease in inflammation was correlated with improved respiratory function and oxygenation; 73\% of patients requiring supplemental oxygenation were discharged on room air, and $50 \%$ of patients on mechanical ventilation were extubated. ${ }^{51}$ Randomized, controlled studies evaluating the BTK inhibitors ibrutinib, acalabrutinib, and zanubrutinib in severe COVID-19 are ongoing and results are awaited.

Hydroxychloroquine has been proposed as a treatment of COVID-19 based on in vitro activity against SARS-CoV-2. Although the mechanism of antiviral activity is poorly defined, hydroxychloroquine has been reported to increase the $\mathrm{pH}$ of endosomes used by the virus for cell entry and to interfere with viral binding to cellular receptors. ${ }^{98}$ Antiinflammatory activity with hydroxychloroquine has also been demonstrated, including the inhibition of TLR signaling and cytokine production. ${ }^{99}$ Nonrandomized, observational studies have reported conflicting results on the clinical benefit of hydroxychloroquine in severe COVID19. ${ }^{100-103}$ However, recent results from randomized, controlled clinical trials have indicated that hydroxychloroquine is not effective in hospitalized patients with severe COVID-19. ${ }^{104-107}$ In addition to dexamethasone, the RECOVERY trial also evaluated the use of hydroxychloroquine $(n=1561)$ versus usual care $(n=3155)$ in hospitalized COVID-19 patients. ${ }^{104}$ The study found no difference in 28-day mortality between patients randomized to receive hydroxychloroquine versus usual care $(26.8 \%$ versus $25.0 \% ; \quad P=0.18) .{ }^{104}$ Moreover, hydroxychloroquine was associated with a longer time to discharge (median, 16 versus 13 days) and with an increased risk for mechanical ventilation or death among patients not on invasive mechanical ventilation at baseline compared to usual care $(\mathrm{HR}=1.12 ; 95 \% \mathrm{CI}, 1.01$ to 1.25$) .{ }^{104}$ The World Health Organization recently discontinued the SOLIDARITY study, a randomized, controlled trial of hydroxychloroquine versus supportive care in hospitalized
COVID-19 patients, as hydroxychloroquine did not reduce mortality (WHO, https://www.who.int/news-room/detail/0407-2020-who-discontinues-hydroxychloroquine-and-lopinavirritonavir-treatment-arms-for-covid-19, last accessed July 18, 2020). Randomized, controlled studies of hydroxychloroquine in patients with mild or moderate COVID-19 disease as well as postexposure prophylaxis similarly showed no clinical benefit. ${ }^{105-107}$

\section{Conclusion}

The rapid spread of SARS-CoV-2 infection has resulted in an unprecedented public health crisis worldwide. Although the majority of cases of COVID-19 are asymptomatic or mild, COVID-19 can manifest as severe viral pneumonia that leads to the need for mechanical ventilation, or death. The natural history of COVID-19 includes an initial stage of viral replication that can be followed by a second stage of immunopathology driven by a hyperinflammatory response to SARS-CoV-2 infection. This review presented the current evidence indicating that a dysregulated host innate immune response underlies the hyperinflammatory syndrome in COVID-19; the disease mechanism is summarized in Figure 1. The syndrome shares overlapping features with a viral-induced hemophagocytic lymphohistiocytosis, including evidence of macrophage activation with a cytokine storm, NK-cell and CD8 ${ }^{+}$T-cell impairment, and hemophagocytic macrophages. Therapies modulating the immune response may be crucial for treating and preventing immunopathology in patients who progress to severe disease. Given the rapidly evolving nature of the COVID-19 pandemic, studies in which the peer-review process has not yet been completed were discussed herein to present the most recent data available, but the findings should be interpreted with caution as the conclusions may change. Future studies are needed for identifying the exact drivers of the pathologic inflammation and biomarkers that predict a hyperinflammatory response to SARS-CoV-2 infection. The results of these studies will enable the identification of the most appropriate immunomodulating agents as well as the optimal timing of such interventions to achieve maximal therapeutic benefit in patients with COVID-19.

\section{Acknowledgment}

We thank Tyler Kalajian for generating the figure showing the disease mechanism in severe COVID-19.

\section{References}

1. Zhu N, Zhang D, Wang W, Li X, Yang B, Song J, Zhao X, Huang B, Shi W, Lu R, Niu P, Zhan F, Ma X, Wang D, Xu W, Wu G, Gao GF, Tan W: A novel coronavirus from patients with pneumonia in China, 2019. N Engl J Med 2020, 382:727-733

2. Lu R, Zhao X, Li J, Niu P, Yang B, Wu H, Wang W, Song H, Huang B, Zhu N, Bi Y, Ma X, Zhan F, Wang L, Hu T, Zhou H, Hu Z, 
Zhou W, Zhao L, Chen J, Meng Y, Wang J, Lin Y, Yuan J, Xie Z, Ma J, Liu WJ, Wang D, Xu W, Holmes EC, Gao GF, Wu G, Chen W, Shi W, Tan W: Genomic characterisation and epidemiology of 2019 novel coronavirus: implications for virus origins and receptor binding. Lancet 2020, 395:565-574

3. Li Q, Guan X, Wu P, Wang X, Zhou L, Tong Y, et al: Early transmission dynamics in Wuhan, China, of novel coronavirus-infected pneumonia. N Engl J Med 2020, 382:1199-1207

4. Huang C, Wang Y, Li X, Ren L, Zhao J, Hu Y, Zhang L, Fan G, Xu J, Gu X, Cheng Z, Yu T, Xia J, Wei Y, Wu W, Xie X, Yin W, Li H, Liu M, Xiao Y, Gao H, Guo L, Xie J, Wang G, Jiang R, Gao Z, Jin Q, Wang J, Cao B: Clinical features of patients infected with 2019 novel coronavirus in Wuhan, China. Lancet 2020, 395:497-506

5. Guan W-J, Ni Z-Y, Hu Y, Liang W-H, Ou C-Q, He J-X, et al; China Medical Treatment Expert Group for Covid-19: Clinical characteristics of Coronavirus disease 2019 in China. N Engl J Med 2020, 382: $1708-1720$

6. Richardson S, Hirsch JS, Narasimhan M, Crawford JM, McGinn T, Davidson KW; Northwell COVID-19 Research Consortium: Presenting characteristics, comorbidities, and outcomes among 5700 patients hospitalized with COVID-19 in the New York City area. JAMA 2020, 323:2052-2059

7. Chen N, Zhou M, Dong X, Qu J, Gong F, Han Y, Qiu Y, Wang J, Liu Y, Wei Y, Xia Ja, Yu T, Zhang X, Zhang L: Epidemiological and clinical characteristics of 99 cases of 2019 novel coronavirus pneumonia in Wuhan, China: a descriptive study. Lancet 2020, 395: $507-513$

8. Zhou F, Yu T, Du R, Fan G, Liu Y, Liu Z, Xiang J, Wang Y, Song B, Gu X, Guan L, Wei Y, Li H, Wu X, Xu J, Tu S, Zhang Y, Chen H, Cao B: Clinical course and risk factors for mortality of adult inpatients with COVID-19 in Wuhan, China: a retrospective cohort study. Lancet 2020, 395:1054-1062

9. Wu C, Chen X, Cai Y, Xia Ja, Zhou X, Xu S, Huang H, Zhang L, Zhou X, Du C, Zhang Y, Song J, Wang S, Chao Y, Yang $\mathrm{Z}, \mathrm{Xu}$ J, Zhou $\mathrm{X}$, Chen $\mathrm{D}$, Xiong W, Xu L, Zhou F, Jiang J, Bai C, Zheng J, Song Y: Risk factors associated with acute respiratory distress syndrome and death in patients with Coronavirus disease 2019 pneumonia in Wuhan, China. JAMA Intern Med 2020, 180:934-943

10. Mehta P, McAuley DF, Brown M, Sanchez E, Tattersall RS, Manson JJ: COVID-19: consider cytokine storm syndromes and immunosuppression. Lancet 2020, 395:1033-1034

11. Ruan Q, Yang K, Wang W, Jiang L, Song J: Clinical predictors of mortality due to COVID-19 based on an analysis of data of 150 patients from Wuhan, China. Intensive Care Med 2020, 46:846-848

12. Del Valle DM, Kim-schulze S, Hsin-hui H, Beckmann ND, Nirenberg S, Wang B, Lavin Y, Swartz T, Madduri D, Stock A, Marron T, Xie H, Patel MK, van Oekelen O, Rahman A, Kovatch P, Aberg J, Schadt E, Jagannath S, Mazumdar M, Charney A, FirpoBetancourt A, Mendu DR, Jhang J, Reich D, Sigel K, CordonCardo C, Feldmann M, Parekh S, Merad M, Gnjatic S: An inflammatory cytokine signature helps predict COVID-19 severity and survival. Nature Medicine 2020, 26:1636-1643

13. Xu Z, Shi L, Wang Y, Zhang J, Huang L, Zhang C, Liu S, Zhao P, Liu H, Zhu L, Tai Y, Bai C, Gao T, Song J, Xia P, Dong J, Zhao J, Wang F-S: Pathological findings of COVID-19 associated with acute respiratory distress syndrome. Lancet Respir Med 2020, 8:420-422

14. Fox SE, Akmatbekov A, Harbert JL, Li G, Quincy Brown J, Vander Heide RS: Pulmonary and cardiac pathology in African American patients with COVID-19: an autopsy series from New Orleans. Lancet Respir Med 2020, 8:681-686

15. Carsana L, Sonzogni A, Nasr A, Rossi RS, Pellegrinelli A, Zerbi P, Rech R, Colombo R, Antinori S, Corbellino M, Galli M, Catena E, Tosoni A, Gianatti A, Nebuloni M: Pulmonary post-mortem findings in a series of COVID-19 cases from northern Italy: a two-centre descriptive study. Lancet Infect Dis 2020, 20:1135-1140
16. Bryce C, Grimes Z, Pujadas E, Ahuja S, Beasley MB, Albrecht R, et al: Pathophysiology of SARS-CoV-2: targeting of endothelial cells renders a complex disease with thrombotic microangiopathy and aberrant immune response. The Mount Sinai COVID-19 autopsy experience. medRxiv 2020. [Epub] doi:10.1016/2020.05.18.20099960

17. Ramos-Casals M, Brito-Zerón P, López-Guillermo A, Khamashta MA, Bosch X: Adult haemophagocytic syndrome. Lancet 2014, 383:1503-1516

18. Ackermann M, Verleden SE, Kuehnel M, Haverich A, Welte T, Laenger F, Vanstapel A, Werlein C, Stark H, Tzankov A, Li WW, Li VW, Mentzer SJ, Jonigk D: Pulmonary vascular endothelialitis, thrombosis, and angiogenesis in COVID-19. N Engl J Med 2020, 383:120-128

19. Varga Z, Flammer AJ, Steiger P, Haberecker M, Andermatt R, Zinkernagel AS, Mehra MR, Schuepbach RA, Ruschitzka F, Moch H: Endothelial cell infection and endotheliitis in COVID-19. Lancet 2020, 395:1417-1418

20. Monteil V, Kwon H, Prado P, Hagelkrüys A, Wimmer RA, Stahl M, Leopoldi A, Garreta E, Hurtado del Pozo C, Prosper F, Romero JP, Wirnsberger G, Zhang H, Slutsky AS, Conder R, Montserrat N, Mirazimi A, Penninger JM: Inhibition of SARS-CoV-2 infections in engineered human tissues using clinical-grade soluble human ACE2. Cell 2020, 181:905-913.e7

21. Bao L, Deng W, Huang B, Gao H, Liu J, Ren L, et al: The pathogenicity of SARS-CoV-2 in hACE2 transgenic mice. Nature 2020, 583:830-833

22. Nicholls JM, Poon LLM, Lee KC, Ng WF, Lai ST, Leung CY, Chu CM, Hui PK, Mak KL, Lim W, Yan KW, Chan KH, Tsang NC, Guan Y, Yuen KY, Malik Peiris JS: Lung pathology of fatal severe acute respiratory syndrome. Lancet 2003, 361:1773-1778

23. Chen G, Wu D, Guo W, Cao Y, Huang D, Wang H, Wang T, Zhang X, Chen H, Yu H, Zhang X, Zhang M, Wu S, Song J, Chen T, Han M, Li S, Luo X, Zhao J, Ning Q: Clinical and immunological features of severe and moderate Coronavirus disease 2019. J Clin Invest 2020, 130:2620-2629

24. Tay MZ, Poh CM, Rénia L, MacAry PA, Ng LFP: The trinity of COVID-19: immunity, inflammation and intervention. Nat Rev Immunol 2020, 20:363-374

25. Schifanella L, Anderson JL, Galli M, Corbellino M, Lai A, Wieking G, Grzywacz B, Klatt NR, Haase AT, Schacker TW: Massive viral replication and cytopathic effects in early COVID-19 pneumonia. arXiv 2020. [Epub] doi:10.1016/arXiv:2005.00004

26. Zhang H, Zhou P, Wei Y, Yue H, Wang Y, Hu M, Zhang S, Cao T, Yang C, Li M, Guo G, Chen X, Chen Y, Lei M, Liu H, Zhao J, Peng P, Wang C-Y, Du R: Histopathologic changes and SARS-CoV2 immunostaining in the lung of a patient with COVID-19. Ann Intern Med 2020, 172:629-632

27. Fink SL, Cookson BT: Apoptosis, pyroptosis, and necrosis: mechanistic description of dead and dying eukaryotic cells. Infect Immun 2005, 73:1907-1916

28. Yang M: Cell pyroptosis, a potential pathogenic mechanism of 2019nCoV infection. SSRN 2020. [Epub] doi:10.2139/ssrn.3527420

29. Yap JKY, Moriyama M, Iwasaki A: Inflammasomes and pyroptosis as therapeutic targets for COVID-19. J Immunol 2020, 205:307-312

30. St John AL, Rathore APS: Early insights into immune responses during COVID-19. J Immunol 2020, 205:555-564

31. Liao M, Liu Y, Yuan J, Wen Y, Xu G, Zhao J, Cheng L, Li J, Wang X, Wang F, Liu L, Amit I, Zhang S, Zhang Z: Single-cell landscape of bronchoalveolar immune cells in patients with COVID19. Nat Med 2020, 26:842-844

32. Mills CD, Kincaid K, Alt JM, Heilman MJ, Hill AM: M-1/M-2 macrophages and the Th1/Th2 paradigm. J Immunol 2000, 164:6166-6173

33. Zhang B, Zhou X, Qiu Y, Feng F, Feng J, Jia Y, Zhu H, Hu K, Liu J, Liu Z, Wang S, Gong Y, Zhou C, Zhu T, Cheng Y, Liu Z, Deng H, Tao F, Ren Y, Cheng B, Gao L, Wu X, Yu L, Huang Z, Mao Z, Song Q, Zhu B, Wang J: Clinical characteristics of 82 death cases with COVID-19. PLoS One 2020, 15(7):e0235458 
34. Ziegler CGK, Allon SJ, Nyquist SK, Mbano IM, Miao VN, Tzouanas CN, et al; HCA Lung Biological Network: SARS-CoV-2 receptor ACE2 is an interferon-stimulated gene in human airway epithelial cells and is detected in specific cell subsets across tissues. Cell 2020, 181:1016-1035.e19

35. Pechkovsky DV, Goldmann T, Ludwig C, Prasse A, Vollmer E, Müller-Quernheim J, Zissel G: CCR2 and CXCR3 agonistic chemokines are differently expressed and regulated in human alveolar epithelial cells type II. Respir Res 2005, 6:75

36. Thorley AJ, Grandolfo D, Lim E, Goldstraw P, Young A, Tetley TD: Innate immune responses to bacterial ligands in the peripheral human lung-role of alveolar epithelial TLR expression and signalling. PLoS One 2011, 6:e21827

37. Chuquimia OD, Petursdottir DH, Periolo N, Fernández C: Alveolar epithelial cells are critical in protection of the respiratory tract by secretion of factors able to modulate the activity of pulmonary macrophages and directly control bacterial growth. Infect Immun 2013, 81:381-389

38. He L, Ding Y, Zhang Q, Che X, He Y, Shen H, Wang H, Li Z, Zhao L, Geng J, Deng Y, Yang L, Li J, Cai J, Qiu L, Wen K, Xu X, Jiang S: Expression of elevated levels of pro-inflammatory cytokines in SARS-CoV-infected ACE2 + cells in SARS patients: relation to the acute lung injury and pathogenesis of SARS. J Pathol 2006, 210: 288-297

39. Blanco-Melo D, Nilsson-Payant BE, Liu W-C, Uhl S, Hoagland D, Møller R, Jordan TX, Oishi K, Panis M, Sachs D, Wang TT, Schwartz RE, Lim JK, Albrecht RA, tenOever BR: Imbalanced host response to SARS-CoV-2 drives development of COVID-19. Cell 2020, 181:1036-1045.e9

40. Hadjadj J, Yatim N, Barnabei L, Corneau A, Boussier J, Smith N, Péré H, Charbit B, Bondet V, Chenevier-Gobeaux C, Breillat P, Carlier N, Gauzit R, Morbieu C, Pène F, Marin N, Roche N, Szwebel T-A, Merkling SH, Treluyer J-M, Veyer D, Mouthon L, Blanc C, Tharaux P-L, Rozenberg F, Fischer A, Duffy D, RieuxLaucat F, Kernéis S, Terrier B: Impaired type I interferon activity and inflammatory responses in severe COVID-19 patients. Science 2020, $369: 718-724$

41. Wang N, Zhan Y, Zhu L, Hou Z, Liu F, Song P, Qiu F, Wang X, Zou X, Wan D, Qian X, Wang S, Guo Y, Yu H, Cui M, Tong G, $\mathrm{Xu} \mathrm{Y,} \mathrm{Zheng} \mathrm{Z,} \mathrm{Lu} \mathrm{Y,} \mathrm{Hong} \mathrm{P:} \mathrm{Retrospective} \mathrm{multicenter} \mathrm{cohort}$ study shows early interferon therapy is associated with favorable clinical responses in COVID-19 patients. Cell Host Microbe 2020, 28:455-464.e2

42. Chen X, Yang X, Zheng Y, Yang Y, Xing Y, Chen Z: SARS coronavirus papain-like protease inhibits the type I interferon signaling pathway through interaction with the STING-TRAF3-TBK1 complex. Protein Cell 2014, 5:369-381

43. Yang Y, Ye F, Zhu N, Wang W, Deng Y, Zhao Z, Tan W: Middle East respiratory syndrome coronavirus ORF4b protein inhibits type I interferon production through both cytoplasmic and nuclear targets. Sci Rep 2015, 5:17554

44. Lui PY, Wong LY, Fung CL, Siu KL, Yeung ML, Yuen KS, Chan CP, Woo PC, Yuen KY, Jin DY: Middle East respiratory syndrome coronavirus $\mathrm{M}$ protein suppresses type $\mathrm{I}$ interferon expression through the inhibition of TBK1-dependent phosphorylation of IRF3. Emerg Microbes Infect 2016, 5:e39

45. Channappanavar R, Fehr Anthony R, Vijay R, Mack M, Zhao J, Meyerholz David K, Perlman S: Dysregulated type I interferon and inflammatory monocyte-macrophage responses cause lethal pneumonia in SARS-CoV-infected mice. Cell Host Microbe 2016, 19: $181-193$

46. Zhou Z, Ren L, Zhang L, Zhong J, Xiao Y, Jia Z, Guo L, Yang J, Wang C, Jiang S, Yang D, Zhang G, Li H, Chen F, Xu Y, Chen M, Gao Z, Yang J, Dong J, Liu B, Zhang X, Wang W, He K, Jin Q, Li M, Wang J: Heightened innate immune responses in the respiratory tract of COVID-19 patients. Cell Host Microbe 2020, 27:883-890.e2
47. Mo X, Jian W, Su Z, Chen M, Peng H, Peng P, Lei C, Li S, Chen R, Zhong N: Abnormal pulmonary function in COVID-19 patients at time of hospital discharge. Eur Respir J 2020, 55:2001217

48. Wang Y, Dong C, Hu Y, Li C, Ren Q, Zhang X, Shi H, Zhou M: Temporal changes of CT findings in 90 patients with COVID-19 pneumonia: a longitudinal study. Radiology 2020, 296:E55-E64

49. Xiong Y, Liu Y, Cao L, Wang D, Guo M, Jiang A, Guo D, Hu W, Yang J, Tang Z, Wu H, Lin Y, Zhang M, Zhang Q, Shi M, Liu Y, Zhou Y, Lan K, Chen Y: Transcriptomic characteristics of bronchoalveolar lavage fluid and peripheral blood mononuclear cells in COVID-19 patients. Emerg Microbes Infect 2020, 9:761-770

50. Zhou Y, Fu B, Zheng X, Wang D, Zhao C, Qi Y, Sun R, Tian Z, Xu X, Wei H: Pathogenic T-cells and inflammatory monocytes incite inflammatory storms in severe COVID-19 patients. Natl Sci Rev 2020, 7:998-1002

51. Roschewski M, Lionakis MS, Sharman JP, Roswarski J, Goy A, Monticelli MA, Roshon M, Wrzesinski SH, Desai JV, Zarakas MA, Collen J, Rose KM, Hamdy A, Izumi R, Wright GW, Chung KK, Baselga J, Staudt LM, Wilson WH: Inhibition of Bruton tyrosine kinase in patients with severe COVID-19. Sci Immunol 2020, 5:eabd0110

52. Wen W, Su W, Tang H, Le W, Zhang X, Zheng Y, Liu X, Xie L, Li J, Ye J, Dong L, Cui X, Miao Y, Wang D, Dong J, Xiao C, Chen W, Wang H: Immune cell profiling of COVID-19 patients in the recovery stage by single-cell sequencing. Cell Discov 2020, 6:31

53. Ong EZ, Chan YFZ, Leong WY, Lee NMY, Kalimuddin S, Haja Mohideen SM, Chan KS, Tan AT, Bertoletti A, Ooi EE, Low JGH: A dynamic immune response shapes COVID-19 progression. Cell Host Microbe 2020, 27:879-882.e2

54. Guo C, Li B, Ma H, Wang X, Cai P, Yu Q, Zhu L, Jin L, Jiang C, Fang J, Liu Q, Zong D, Zhang W, Lu Y, Li K, Gao X, Fu B, Liu L, Ma X, Weng J, Wei H, Jin T, Lin J, Qu K: Single-cell analysis of severe COVID-19 patients reveals a monocyte-driven inflammatory storm attenuated by tocilizumab. Nat Commun 2020, 11:3924

55. Page TH, Urbaniak AM, Espirito Santo AI, Danks L, Smallie T, Williams LM, Horwood NJ: Bruton's tyrosine kinase regulates TLR7/8-induced TNF transcription via nuclear factor-[kappa]B recruitment. Biochem Biophys Res Commun 2018, 499:260-266

56. Ito M, Shichita T, Okada M, Komine R, Noguchi Y, Yoshimura A, Morita R: Bruton's tyrosine kinase is essential for NLRP3 inflammasome activation and contributes to ischaemic brain injury. Nat Commun 2015, 6:7360

57. Bittner ZA, Liu X, Dickhöfer S, Kalbacher H, Bosch K, Andreeva L, Marcu A, Stevanovic S, Mangan M, Düwell P, Lovotti M, Herster F, Löffler MW, Shankar S, Tapia-Abellán A, Wolz O-O, Schilling NA, Kümmerle-Deschner J, Wagner S, Delor A, Grimbacher B, Wu H, Latz E, Weber ANR: BTK operates a phospho-tyrosine switch to regulate NLRP3 inflammasome activity. bioRxiv 2019:864702

58. Akira S, Uematsu S, Takeuchi O: Pathogen recognition and innate immunity. Cell 2006, 124:783-801

59. Sheahan T, Morrison TE, Funkhouser W, Uematsu S, Akira S, Baric RS, Heise MT: MyD88 is required for protection from lethal infection with a mouse-adapted SARS-CoV. PLoS Pathog 2008, 4: e1000240

60. Wilk AJ, Rustagi A, Zhao NQ, Roque J, Martínez-Colón GJ, McKechnie JL, Ivison GT, Ranganath T, Vergara R, Hollis T, Simpson LJ, Grant P, Subramanian A, Rogers AJ, Blish CA: A single-cell atlas of the peripheral immune response in patients with severe COVID-19. Nat Med 2020, 26:1070-1076

61. Zheng M, Gao Y, Wang G, Song G, Liu S, Sun D, Xu Y, Tian Z: Functional exhaustion of antiviral lymphocytes in COVID-19 patients. Cell Mol Immunol 2020, 17:533-535

62. Wang F, Nie J, Wang H, Zhao Q, Xiong Y, Deng L, Song S, Ma Z, Mo P, Zhang Y: Characteristics of peripheral lymphocyte subset alteration in COVID-19 pneumonia. J Infect Dis 2020, 221: $1762-1769$

63. Giamarellos-Bourboulis EJ, Netea MG, Rovina N, Akinosoglou K, Antoniadou A, Antonakos N, Damoraki G, Gkavogianni T, 
Adami M-E, Katsaounou P, Ntaganou M, Kyriakopoulou M, Dimopoulos G, Koutsodimitropoulos I, Velissaris D, Koufargyris P, Karageorgos A, Katrini K, Lekakis V, Lupse M, Kotsaki A, Renieris G, Theodoulou D, Panou V, Koukaki E, Koulouris N, Gogos C, Koutsoukou A: Complex immune dysregulation in COVID-19 patients with severe respiratory failure. Cell Host Microbe 2020, 27:992-1000.e3

64. McKechnie JL, Blish CA: The innate immune system: fighting on the front lines or fanning the flames of COVID-19? Cell Host Microbe 2020, 27:863-869

65. Carlin LE, Hemann EA, Zacharias ZR, Heusel JW, Legge KL: Natural killer cell recruitment to the lung during influenza A virus infection is dependent on CXCR3, CCR5, and virus exposure dose. Front Immunol 2018, 9:781

66. Cifaldi L, Prencipe G, Caiello I, Bracaglia C, Locatelli F, De Benedetti F, Strippoli R: Inhibition of natural killer cell cytotoxicity by IL-6: implications for the pathogenesis of macrophage activation syndrome. Arthritis Rheumatol 2015, 67:3037-3046

67. Ivagnès A, Messaoudene M, Stoll G, Routy B, Fluckiger A, Yamazaki T, Iribarren K, Duong CPM, Fend L, Caignard A, Cremer I, LeCesne A, Adam J, Honoré C, Mir O, Chaigneau L, Berger A, Validire P, Christidis C, Brun-Ly VL, Smyth MJ, Mariette X, Salomon BL, Kroemer G, Rusakiewicz S, Zitvogel L: TNFR2/BIRC3-TRAF1 signaling pathway as a novel NK cell immune checkpoint in cancer. Oncoimmunology 2018, 7:e1386826

68. Vabret N, Britton GJ, Gruber C, Hegde S, Kim J, Kuksin M, et al; Sinai Immunology Review Project: Immunology of COVID-19: current state of the science. Immunity 2020, 52:910-941

69. Chen Y, Feng Z, Diao B, Wang R, Wang G, Wang C, Tan Y, Liu L, Wang C, Liu Y, Liu Y, Yuan Z, Ren L, Wu Y: The novel severe acute respiratory syndrome coronavirus 2 (SARS-CoV-2) directly decimates human spleens and lymph nodes. medRxiv 2020. [Epub] doi:10.1101/2020.03.27.20045427

70. Middleton EA, He X-Y, Denorme F, Campbell RA, Ng D, Salvatore SP, Mostyka M, Baxter-Stoltzfus A, Borczuk AC, Loda M, Cody MJ, Manne BK, Portier I, Harris E, Petrey AC, Beswick EJ, Caulin AF, Iovino A, Abegglen LM, Weyrich AS, Rondina MT, Egeblad M, Schiffman JD, Yost CC: Neutrophil extracellular traps contribute to immunothrombosis in COVID-19 acute respiratory distress syndrome. Blood 2020, 136:1169-1179

71. Zuo Y, Yalavarthi S, Shi H, Gockman K, Zuo M, Madison JA, Blair C, Weber A, Barnes BJ, Egeblad M, Woods RJ, Kanthi Y, Knight JS: Neutrophil extracellular traps in COVID-19. JCI Insight 2020, 5:e138999

72. Barnes BJ, Adrover JM, Baxter-Stoltzfus A, Borczuk A, CoolsLartigue J, Crawford JM, Daßler-Plenker J, Guerci P, Huynh C, Knight JS, Loda M, Looney MR, McAllister F, Rayes R, Renaud S, Rousseau S, Salvatore S, Schwartz RE, Spicer JD, Yost CC, Weber A, Zuo Y, Egeblad M: Targeting potential drivers of COVID-19: neutrophil extracellular traps. J Exp Med 2020, 217: e20200652

73. Porto BN, Stein RT: Neutrophil extracellular traps in pulmonary diseases: too much of a good thing? Front Immunol 2016, 7:311

74. Feldstein LR, Rose EB, Horwitz SM, Collins JP, Newhams MM, Son MBF, et al; Overcoming COVID-19 Investigators; CDC COVID-19 Response Team: Multisystem inflammatory syndrome in UNITED STATES children and adolescents. N Engl J Med 2020, 383:334-346

75. Dufort EM, Koumans EH, Chow EJ, Rosenthal EM, Muse A, Rowlands J, Barranco MA, Maxted AM, Rosenberg ES, Easton D, Udo T, Kumar J, Pulver W, Smith L, Hutton B, Blog D, Zucker H: Multisystem inflammatory syndrome in children in New York State. N Engl J Med 2020, 383:347-358

76. Lee PY, Day-Lewis M, Henderson LA, Friedman K, Lo J, Roberts JE, Lo MS, Platt CD, Chou J, Hoyt KJ, Baker AL, Banzon T, Chang MH, Cohen E, de Ferranti S, Dionne A, Habiballah S, Halyabar O, Hausmann JS, Hazen M, Janssen E, Meidan E,
Nelson RW, Nguyen AA, Sundel RP, Dedeoglu F, Nigrovic PA, Newburger JW, Son MBF: Distinct clinical and immunological features of SARS-COV-2-induced multisystem inflammatory syndrome in children. J Clin Invest 2020, 130:5942-5950

77. Verdoni L, Mazza A, Gervasoni A, Martelli L, Ruggeri M, Ciuffreda M, Bonanomi E, D'Antiga L: An outbreak of severe Kawasaki-like disease at the Italian epicentre of the SARS-CoV-2 epidemic: an observational cohort study. Lancet 2020, 395:1771-1778

78. The RECOVERY Collaborative Group: Dexamethasone in hospitalized patients with Covid-19-preliminary report. N Engl J Med 2020. [Epub ahead of print] doi:10.1056/NEJMoa2021436

79. Wölfel R, Corman VM, Guggemos W, Seilmaier M, Zange S, Müller MA, Niemeyer D, Jones TC, Vollmar P, Rothe C, Hoelscher M, Bleicker T, Brünink S, Schneider J, Ehmann R, Zwirglmaier K, Drosten C, Wendtner C: Virological assessment of hospitalized patients with COVID-2019. Nature 2020, 581:465-469

80. Arabi YM, Mandourah Y, Al-Hameed F, Sindi AA, Almekhlafi GA, Hussein MA, Jose J, Pinto R, Al-Omari A, Kharaba A, Almotairi A, Khatib KA, Alraddadi B, Shalhoub S, Abdulmomen A, Qushmaq I, Mady A, Solaiman O, Al-Aithan AM, Al-Raddadi R, Ragab A, Balkhy HH, Harthy AA, Deeb AM, Mutairi HA, Al-Dawood A, Merson L, Hayden FG, Fowler RA: Corticosteroid therapy for critically ill patients with Middle East respiratory syndrome. Am J Respir Crit Care Med 2018, 197:757-767

81. Lee N, Allen Chan KC, Hui DS, Ng EKO, Wu A, Chiu RWK, Wong VWS, Chan PKS, Wong KT, Wong E, Cockram CS, Tam JS, Sung JJY, Lo YMD: Effects of early corticosteroid treatment on plasma SARS-associated Coronavirus RNA concentrations in adult patients. J Clin Virol 2004, 31:304-309

82. Teachey DT, Rheingold SR, Maude SL, Zugmaier G, Barrett DM, Seif AE, Nichols KE, Suppa EK, Kalos M, Berg RA, Fitzgerald JC, Aplenc R, Gore L, Grupp SA: Cytokine release syndrome after blinatumomab treatment related to abnormal macrophage activation and ameliorated with cytokine-directed therapy. Blood 2013, 121: $5154-5157$

83. Maude SL, Frey N, Shaw PA, Aplenc R, Barrett DM, Bunin NJ, Chew A, Gonzalez VE, Zheng Z, Lacey SF, Mahnke YD, Melenhorst JJ, Rheingold SR, Shen A, Teachey DT, Levine BL, June CH, Porter DL, Grupp SA: Chimeric antigen receptor T cells for sustained remissions in leukemia. $\mathrm{N}$ Engl $\mathrm{J}$ Med 2014, 371: $1507-1517$

84. Xu X, Han M, Li T, Sun W, Wang D, Fu B, Zhou Y, Zheng X, Yang Y, Li X, Zhang X, Pan A, Wei H: Effective treatment of severe COVID-19 patients with tocilizumab. Proc Natl Acad Sci U S A 2020, 117:10970-10975

85. Sciascia $\mathrm{S}$, Aprà $\mathrm{F}$, Baffa $\mathrm{A}$, Baldovino $\mathrm{S}$, Boaro $\mathrm{D}$, Boero $\mathrm{R}$, Bonora S, Calcagno A, Cecchi I, Cinnirella G, Converso M, Cozzi M, Crosasso P, De Iaco F, Di Perri G, Eandi M, Fenoglio R, Giusti M, Imperiale D, Imperiale G, Livigni S, Manno E, Massara C, Milone V, Natale G, Navarra M, Oddone V, Osella S, Piccioni P, Radin M, Roccatello D, Rossi D: Pilot prospective open, single-arm multicentre study on off-label use of tocilizumab in patients with severe COVID19. Clin Exp Rheumatol 2020, 38:529-532

86. Luo P, Liu Y, Qiu L, Liu X, Liu D, Li J: Tocilizumab treatment in COVID-19: a single center experience. J Med Virol 2020, 92: 814-818

87. Somers EC, Eschenauer GA, Troost JP, Golob JL, Gandhi TN, Wang L, Zhou N, Petty LA, Baang JH, Dillman NO, Frame D, Gregg KS, Kaul DR, Nagel J, Patel TS, Zhou S, Lauring AS, Hanauer DA, Martin E, Sharma P, Fung CM, Pogue JM: Tocilizumab for treatment of mechanically ventilated patients with COVID-19. Clin Infect Dis 2020. [Epub ahead of print] doi:10.1093/cid/ciaa954

88. Guaraldi G, Meschiari M, Cozzi-Lepri A, Milic J, Tonelli R, Menozzi M, Franceschini E, Cuomo G, Orlando G, Borghi V, Santoro A, Di Gaetano M, Puzzolante C, Carli F, Bedini A, Corradi L, Fantini R, Castaniere I, Tabbì L, Girardis M, Tedeschi S, Giannella M, Bartoletti M, Pascale R, Dolci G, Brugioni L, 
Pietrangelo A, Cossarizza A, Pea F, Clini E, Salvarani C, Massari M, Viale PL, Mussini C: Tocilizumab in patients with severe COVID-19: a retrospective cohort study. Lancet Rheumatol 2020, 2:e474-e484

89. Cavalli G, De Luca G, Campochiaro C, Della-Torre E, Ripa M, Canetti D, Oltolini C, Castiglioni B, Tassan Din C, Boffini N, Tomelleri A, Farina N, Ruggeri A, Rovere-Querini P, Di Lucca G, Martinenghi S, Scotti R, Tresoldi M, Ciceri F, Landoni G, Zangrillo A, Scarpellini P, Dagna L: Interleukin-1 blockade with high-dose anakinra in patients with COVID-19, acute respiratory distress syndrome, and hyperinflammation: a retrospective cohort study. Lancet Rheumatol 2020, 2:e325-e331

90. Huet $\mathrm{T}$, Beaussier H, Voisin O, Jouveshomme S, Dauriat G, Lazareth I, Sacco E, Naccache J-M, Bézie Y, Laplanche S, Le Berre A, Le Pavec J, Salmeron S, Emmerich J, Mourad J-J, Chatellier G, Hayem G: Anakinra for severe forms of COVID-19: a cohort study. Lancet Rheumatol 2020, 2:e393-e400

91. Mehta P, Cron RQ, Hartwell J, Manson JJ, Tattersall RS: Silencing the cytokine storm: the use of intravenous anakinra in haemophagocytic lymphohistiocytosis or macrophage activation syndrome. Lancet Rheumatol 2020, 2:e358-e367

92. Shakoory B, Carcillo JA, Chatham WW, Amdur RL, Zhao H, Dinarello CA, Cron RQ, Opal SM: Interleukin-1 receptor blockade is associated with reduced mortality in sepsis patients with features of macrophage activation syndrome: reanalysis of a prior phase III trial. Crit Care Med 2016, 44:275-281

93. Niemann CU, Herman SEM, Maric I, Gomez-Rodriguez J, Biancotto A, Chang BY, Martyr S, Stetler-Stevenson M, Yuan CM, Calvo KR, Braylan RC, Valdez J, Lee YS, Wong DH, Jones J, Sun C, Marti GE, Farooqui MZH, Wiestner A: Disruption of in vivo chronic lymphocytic leukemia tumor-microenvironment interactions by ibrutinib-findings from an investigator-initiated phase II study. Clin Cancer Res 2016, 22:1572-1582

94. Vos JM, Tsakmaklis N, Patterson CJ, Meid K, Castillo JJ, Brodsky P, Ganz T, Pals ST, Kersten MJ, Xu L, Yang G, Treon SP, Hunter ZR: CXCL13 levels are elevated in patients with Waldenström macroglobulinemia, and are predictive of major response to ibrutinib. Haematologica 2017, 102:e452-e455

95. Miklos D, Cutler CS, Arora M, Waller EK, Jagasia M, Pusic I, Flowers ME, Logan AC, Nakamura R, Blazar BR, Li Y, Chang S, Lal I, Dubovsky J, James DF, Styles L, Jaglowski S: Ibrutinib for chronic graft-versus-host disease after failure of prior therapy. Blood 2017, 130:2243-2250

96. Florence JM, Krupa A, Booshehri LM, Davis SA, Matthay MA, Kurdowska AK: Inhibiting Bruton's tyrosine kinase rescues mice from lethal influenza-induced acute lung injury. Am J Physiol Lung Cell Mol Physiol 2018, 315:L52-L58

97. Treon SP, Castillo JJ, Skarbnik AP, Soumerai JD, Ghobrial IM, Guerrera ML, Meid K, Yang G: The BTK inhibitor ibrutinib may protect against pulmonary injury in COVID-19-infected patients. Blood 2020, 135:1912-1915

98. Fantini J, Chahinian H, Yahi N: Synergistic antiviral effect of hydroxychloroquine and azithromycin in combination against SARSCoV-2: what molecular dynamics studies of virus-host interactions reveal. Int J Antimicrob Agents 2020, 56:106020

99. Schrezenmeier E, Dörner T: Mechanisms of action of hydroxychloroquine and chloroquine: implications for rheumatology. Nat Rev Rheumatol 2020, 16:155-166
100. Gautret P, Lagier J-C, Parola P, Hoang VT, Meddeb L, Mailhe M, Doudier B, Courjon J, Giordanengo V, Vieira VE, Tissot Dupont H, Honoré S, Colson P, Chabrière E, La Scola B, Rolain J-M, Brouqui P, Raoult D: Hydroxychloroquine and azithromycin as a treatment of COVID-19: results of an open-label non-randomized clinical trial. Int J Antimicrob Agents 2020, 56:105949

101. Arshad S, Kilgore P, Chaudhry ZS, Jacobsen G, Wang DD, Huitsing K, et al; Henry Ford COVID-19 Task Force: Treatment with hydroxychloroquine, azithromycin, and combination in patients hospitalized with COVID-19. Int J Infect Dis 2020, 97: 396-403

102. Geleris J, Sun Y, Platt J, Zucker J, Baldwin M, Hripcsak G, Labella A, Manson DK, Kubin C, Barr RG, Sobieszczyk ME, Schluger NW: Observational study of hydroxychloroquine in hospitalized patients with Covid-19. N Engl J Med 2020, 382: $2411-2418$

103. Mahévas M, Tran V-T, Roumier M, Chabrol A, Paule R, Guillaud C, Fois E, Lepeule R, Szwebel T-A, Lescure F-X, Schlemmer F, Matignon M, Khellaf M, Crickx E, Terrier B, Morbieu C, Legendre P, Dang J, Schoindre Y, Pawlotsky J-M, Michel M, Perrodeau E, Carlier N, Roche N, de Lastours V, Ourghanlian C, Kerneis S, Ménager P, Mouthon L, Audureau E, Ravaud P, Godeau B, Gallien S, Costedoat-Chalumeau N: Clinical efficacy of hydroxychloroquine in patients with COVID-19 pneumonia who require oxygen: observational comparative study using routine care data. BMJ 2020, 369:m1844

104. Horby P, Mafham M, Linsell L, Bell JL, Staplin N, Emberson JR, Wiselka M, Ustianowski A, Elmahi E, Prudon B, Whitehouse A, Felton T, Williams J, Faccenda J, Underwood J, Baillie JK, Chappell L, Faust SN, Jaki T, Jeffery K, Lim WS, Montgomery A, Rowan K, Tarning J, Watson JA, White NJ, Juszczak E, Haynes R, Landray MJ; RECOVERY Collaborative Group: Effect of hydroxychloroquine in hospitalized patients with COVID-19: preliminary results from a multi-centre, randomized, controlled trial. medRxiv 2020 [Epub] doi:10.1101/2020.07.15.20151852

105. Cavalcanti AB, Zampieri FG, Rosa RG, Azevedo LCP, Veiga VC, Avezum A, Damiani LP, Marcadenti A, Kawano-Dourado L, Lisboa T, Junqueira DLM, de Barros e Silva PGM, Tramujas L, Abreu-Silva EO, Laranjeira LN, Soares AT, Echenique LS, Pereira AJ, Freitas FGR, Gebara OCE, Dantas VCS, Furtado RHM, Milan EP, Golin NA, Cardoso FF, Maia IS, Hoffmann Filho CR, Kormann APM, Amazonas RB, Bocchi de Oliveira MF, SerpaNeto A, Falavigna M, Lopes RD, Machado FR, Berwanger O: Hydroxychloroquine with or without azithromycin in mild-tomoderate Covid-19. N Engl J Med 2020, 383:2041-2052

106. Mitjà $\mathrm{O}$, Corbacho-Monné $\mathrm{M}$, Ubals $\mathrm{M}$, Tebe $\mathrm{C}$, Peñafiel J, Tobias $\mathrm{A}$, et al; BCN PEP-CoV-2 Research Group: Hydroxychloroquine for early treatment of adults with mild Covid-19: a randomizedcontrolled trial. Clin Infect Dis 2020. [Epub ahead of print] doi:10. 1093/cid/ciaa09

107. Boulware DR, Pullen MF, Bangdiwala AS, Pastick KA, Lofgren SM, Okafor EC, Skipper CP, Nascene AA, Nicol MR, Abassi M, Engen NW, Cheng MP, LaBar D, Lother SA, MacKenzie LJ, Drobot G, Marten N, Zarychanski R, Kelly LE, Schwartz IS, McDonald EG, Rajasingham R, Lee TC, Hullsiek KH: A randomized trial of hydroxychloroquine as postexposure prophylaxis for COVID19. N Engl J Med 2020, 383:517-525 